\title{
Perilaku Trenggiling (Manis javanica) Hewan Yang Hampir Punah
}

\author{
Muhammad Radhi ${ }^{1}$ \\ ${ }^{1}$ Fakultas Sains dan Teknologi, Universitas Islam Negeri Ar-Raniry, Kota Pelajar dan Mahasiswa, \\ Darussalam, Banda Aceh 23111 \\ *Korespondensi penulis : m.radhi@gmail.com
}

\begin{abstract}
Abstrak
Trenggiling (Manis javanica) merupakan salah satu hewan di Indonesia kini telah mencapai ambang kepunahan. Berdasarkan UU No. 5/1990 dan PP No. 17/1999 dan CITES: Convention on International Trade in Endangered Species of Wild Fauna and Flora) trenggiling masuk kategori appendix I. Dalam aktivitas mendapatkan pakan, trenggiling menggunakan indera penciumannya, trenggiling menggali dengan cakar kaki depannya hingga semut atau rayap keluar dari sarang. Aktivitas seekor trenggiling dapat berlangsung sepanjang hari tetapi lebih tinggi ketika malam hari (nokturnal). Trenggiling sangat pandai memanjat dibandingkan dengan berjalan. Trenggiling jantan harus bersaing dengan trenggiling jantan lainnya untuk mendapatkan betina Trenggiling menyelamatkan dirinya dari predator-predator tersebut dengan berbagai cara. Dimulai dengan menegakkan sisik, melingkarkan badan hingga menyemprotkan cairan berbau busuk dari kelenjar anal untuk mengusir predatorpredator tersebut.
\end{abstract}

\section{Kata kunci: trenggiling, Manis javanica, perilaku, penuebaran dan klasifikasi}

\section{Pendahuluan}

Pengembangan potensi sumber daya alam khususnya satwa, merupakan hal yang strategis terutama bila dikaitkan dengan potensi unggulan di setiap daerah. Hal ini mengingat Indonesia sangat kaya dengan keanekaragaman hayati akibat letak secara geografis di lintasan garis khatulistiwa. Meningkatnya jumlah populasi manusia dari tahun ketahun, mengakibatkan pemanfaatan sumber kekayaan alam baik melalui eksploitasi maupun pembukaan hutan untuk dijadikan wilayah perumahan, perindustrian, pertanian, dan sebagainya semakin meluas. Eksploitasi yang dilakukan tanpa memperhatikan kelestarian lingkungan dapat menyebabkan kerusakan hutan, polusi air maupun udara, dan sebagainya. Kerusakan hutan dapat mengakibatkan beberapa jenis satwa terancam keberadaannya.

Indonesia negara yang kaya dengan keanekaragaman hayati tertinggi kedua di dunia setelah Brasil. Dengan luas total daratan 1,3\% dari seluruh permukaan bumi, Indonesia memiliki $10 \%$ tumbuhan berbunga (27.000 jenis), $12 \%$ Mamalia (515 jenis), $16 \%$ satwa Amphibia (270 jenis), dan $17 \%$ Aves (1539 jenis) (KLH dan Kophalindo 1994). Tetapi sangat disayangkan hal tersebut belum diikuti dengan pemanfaatan yang baik dalam bidang IPTEK. Eksploitasi alam hayati umumnya masih pada taraf untuk kepentingan ekonomi. Sehingga ketika kekayaan tersebut mulai berkurang, baru sedikit data ilmiah yang dihasilkannya.

Beberapa hewan di Indonesia kini telah mencapai ambang kepunahan, salah satunya adalah trenggiling (Manis javanica). Berdasarkan UU No. 5/1990 dan PP No. 17/1999, trenggiling merupakan hewan yang dilindungi oleh pemerintah RI dan menurut Soehartono dan Mardiastuti (2003) dalam Konvensi Internasional Perdagangan Hewan Liar (CITES: Convention on International Trade in Endangered Species of Wild Fauna and Flora) trenggiling masuk kategori appendix I, artinya suatu jenis hewan yang pada saat ini 
termasuk kedalam kategori terancam punah, namun memiliki kemungkinan terancam punah jika perdagangannya tidak diatur. Meskipun demikian, perdagangan secara ilegal tetap terjadi dan menjadi indikasi bahwa permintaan pasar terhadap satwa ini terus meningkat sehingga suplay trenggiling harus tersedia secara kontinyu dan berkelanjutan (Novriyanti 2011).

Trenggiling merupakan salah satu hewan yang telah mendapat perhatian khusus oleh CITES sejak tahun 1985. Hal ini dikarenakan semakin maraknya perdagangan ilegal trenggiling yang menyebabkan populasi trenggiling semakin menurun. Maraknya perburuan trenggiling disebabkan kepercayaan masyarakat terhadap sisik trenggiling yang dianggap dapat menyembuhkan keracunan, inflamasi, scabies, dan rematik (Nowak 1999). Selain itu pengrusakan habitat trenggiling merupakan faktor lain yang menyebabkan semakin berkurangnya jumlah trenggiling yang dapat bertahan hidup.

Perburuan liar terhadap satwa ini semakin meningkat, sehingga populasi di alam menurun secara drastis. Hal ini didorong dengan kondisi perdagangan trenggiling di Indonesia semakin marak sejak tahun 2000-an dan informasi terbaru terjadi pada awal Mei 2012 di mana petugas Balai Karantina Kelas II Cilegon-Banten menemukan truk boks pendingin thermo king yang ditinggalkan oleh pemiliknya di area parkir Pelabuhan Merak, berisi 4.124,12 kilogram daging beku trenggiling dan sisik 31,36 kilogram trenggiling (Hamzah 2012). Temuan tersebut merugikan negara sebanyak 8,23 milyar terutama apabila sudah menjadi daging siap saji di rumah makan China. Volume ekspor trenggiling secara ilegal dalam satu bulan terakhir mencapai 10-20 ton dengan omzet ratusan milyar rupiah.

Nilai ekonomis penjualan trenggiling sangat tinggi yaitu harga daging trenggiling di Indonesia sekitar Rp 250.000,- per kilogram. Harga daging trenggiling di pasar internasional mencapai \$ 112 AS per kilogram (sekitar Rp 1 juta) dan harga jual daging trenggiling di restoran mencapai \$210 AS per kilogram (sekitar Rp 1,9 juta). Harga sisik trenggiling mencapai \$1 AS per keping. Berdasarkan nilai jual yang tinggi tersebut, masyarakat berusaha untuk memenuhi permintaan ekspor dengan melakukan perburuan ilegal, sehingga populasi trenggiling di alam cenderung menurun lebih dari $50 \%$ dalam waktu 15 tahun terakhir (Adiseno 2008).

Sehingga pertumbuhan populasi manusia ini mempunyai pengaruh yang sangat besar terhadap persediaan sumber daya alam termasuk satwa liar. Upaya yang dilakukan pemerintah untuk menyelamatkan kehidupan satwa liar dari ancaman kepunahan, yaitu melakukan kegiatan konservasi satwa liar dengan cara menyediakan suaka-suaka alam (tempat berlindung dan berkembangbiaknya satwa liar), seperti Taman Nasional, Suaka Margasatwa, dan Cagar Alam. Kegiatan konservasi ini dibedakan menjadi dua, yaitu konservasi in situ (di habitat asli) dan konservasi ex situ (di luar habitat asli) (Akmal et al., 2014a). Mengatasi penurunan populasi trenggiling di alam, perlu diantisipasi dengan melakukan penangkaran sebagai upaya untuk mempertahankan populasi yang mulai terancam punah. Prinsip yang harus diperhatikan dalam upaya penangkaran adalah memenuhi kebutuhan trenggiling untuk hidup layak dengan mengkondisikan lingkungan seperti pada habitat alami, sehingga trenggiling dapat bereproduksi dengan baik (Sawitri et al. 2012)

Trenggiling merupakan salah satu mamalia yang unik dan menarik. Salah satu keunikkan tersebut dapat terlihat dari morfologi tubuhnya ditutupi sisiksisik yang keras seperti reptil (Breen 2012). Selain itu kemampuan penciuman trenggiling lebih baik dibandingkan dengan kemampuan penglihatannya (Robinson 2005). Hal tersebut sangat berhubungan dengan aktivitasnya yang lebih banyak terjadi pada malam hari (nokturnal) serta aktif menemukan sarang semut dan rayap untuk mendapatkan makanan. Makanan utama dari trenggiling adalah semut (Ordo Hymenoptera) dan rayap (Ordo Isoptera). Diantara keduanya semut merah tanah (Myrmicaria sp) merupakan makanan yang lebih disukai trenggiling (Heryatin 1983).

Kepunahan trenggiling pada umumnya disebabkan oleh tingkah laku manusia yang tidak bertanggungjawab. Perburuan liar dan penjualan trenggiling secara ilegal menyebabkan berkurangnya populasi di alam (Akmal et al., 2014a; Akmal et al., 2019). Di samping itu, hutan yang merupakan habitat trenggiling, banyak dijadikan sebagai lahan 
perkebunan untuk mencukupi kebutuhan pangan manusia, sehingga habitat sebagai tempat hidup trenggiling yang layak, sudah hampir tidak ada lagi (Sawitri et al. 2012).

Pemanfaatan satwa liar yang diambil dari alam, dikhawatirkan akan dapat menyebabkan penurunan jumlah populasi, sehingga perlu adanya suatu upaya penanganan yang mengarah pada kegiatan konservasi. Konservasi merupakan upaya yang bertujuan untuk melestarikan dan melindungi keanekaragaman genetika, spesies atau jenis dan untuk memanfaatkannya bagi kepentingan manusia. Konservasi secara in situ dan ex situ merupakan kegiatan yang saat ini banyak dilakukan terhadap satwa liar. Informasi tentang status biologi reproduksi dari satwa liar sangat penting untuk pelaksanaan kegiatan konservasi ex situ. Salah satu aspek dalam biologi reproduksi satwa liar adalah pengetahuan tentang anatomi dan fisiologi dari organ reproduksi baik betina maupun jantan, yang dapat digunakan untuk proses pembudidayaan, perkembangbiakkan, serta bahan penentu kebijakan dalam pengelolaan kehidupan satwa di penangkaran (Tethool 2011).

Mengatasi penurunan populasi trenggiling di alam, perlu diantisipasi dengan melakukan penangkaran sebagai upaya untuk mempertahankan populasi yang mulai terancam punah. Prinsip yang harus diperhatikan dalam upaya penangkaran adalah memenuhi kebutuhan trenggiling untuk hidup layak dengan mengkondisikan lingkungan seperti pada habitat alami, sehingga trenggiling dapat bereproduksi dengan baik. Selain itu, keberhasilan upaya penangkaran trenggiling sangat didukung oleh pengetahuan dasar tentang pola perilaku yang dibutuhkan untuk pemenuhan kebutuhan hidup satwa tersebut. Pengetahuan tentang cara pemberian pakan dan perilaku makan merupakan faktor penentu yang sangat penting untuk mempertahankan populasi satwaliar tersebut. Menurut Suratmo (1979), pemahaman tentang perilaku perlu diketahui untuk dapat menguasai ilmu atau pengetahuan tentang ekologi populasi dan pakan dalam rangka untuk mendapatkan keahlian dalam pembinaan populasi.

Informasi mengenai perilaku trenggiling di penangkaran masih sangat terbatas, padahal perilaku dapat memberikan gambaran dan informasi tentang pakan (cara makan, konsumsi, waktu pemberian makan dan pola makan), tidur (posisi dan cara tidur, waktu tidur), dan bergerak (berjalan, memanjat, berdiri). Informasi ini dapat menunjang sistem penangkaran yang lebih baik, sehingga populasi trenggiling di masa yang akan datang setidaknya dapat dipertahankan dan lebih dikembangkan lagi. Informasi ini bertujuan untuk memperoleh informasi tentang perilaku trenggiling dalam kandang agar dapat meningkatkan keberhasilan penangkaran. Informasi yang diperoleh diharapkan mampu memberikan gambaran tentang pengelolaan dan penangkaran trenggiling bagi saya sendiri sebagai kajian dalam penelitian saya, pengusaha atau masyarakat yang berminat menangkarkan satwa ini agar efektif dan efisien, sehingga dapat berkembang lebih baik untuk mempertahankan populasi dari kepunahan

\section{TRENGGILING (MANIS JAVANICA DESMAREST,1822)}

Trenggiling merupakan salah satu jenis mamalia langka yang menjadi kekayaan alam hayati Indonesia. Nama trenggiling berasal dari bahasa melayu yakni pengguling atau guling yang artinya menggulung atau melingkar seperti bola. Klasifikasi dan Penyebaran Trenggiling ( $M$. javanica)

Mamalia ini dalam taksonominya termasuk ke dalam

Kingdom : Animalia

Phylum : Chordata

Class : Mamalia

Ordo : Pholidota

Famili : Manidae

Genus : Manis (Linnaeus 1758) (Corbet dan Hill 1992). 


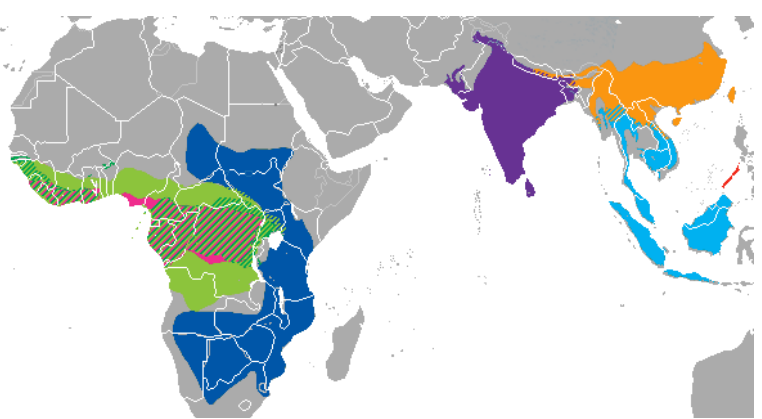

Gambar 1. Trenggiling yang terdistribusi di hutan-hutan tropis Asia dan Afrika.

Terdapat tujuh spesies trenggiling yang terdistribusi di hutan-hutan tropis Asia dan Afrika. Spesies trenggiling Asia yaitu M. javanica, M. crassicaudata, dan M. pentadactyla. Adapun spesies trenggiling Afrika yaitu $M$. gigantea, M. temminckii, M. tricuspis, dan $M$. tetradactyla (Robinson 2005). Gaubert dan Antunes (2005), mengusulkan berdasarkan perbedaan beberapa karakteristik morfologi dan DNAnya bahwa spesies trenggiling yang terdapat di pulau Palawan (Filipina) merupakan spesies tersendiri. Sebelumnya spesies tersebut dianggap sebagai $M$. Javanica liha pada Gambar 1 . Sehingga saat ini diusulkan oleh mereka bahwa jumlah spesies trenggiling ada delapan.

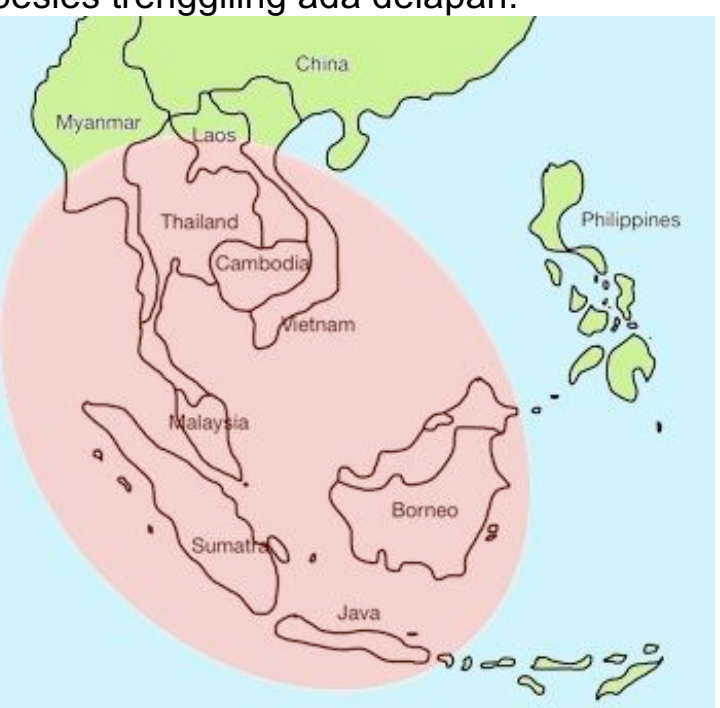

Gambar 2. Penyebaran spesies M. Javanica (warna merah jambu)

Penyebaran spesies $M$. javanica di Indonesia meliputi hutan hujan tropis daerah Sumatera, Jawa, Kalimantan, dan pulaupulau kecil dari Riau, Pulau Lingga, Bangka, Belitung, Nias, Pagai, Pulau Natuna, Karimata, Bali, serta Lombok (Gambar 2) (Corbet dan Hill 1992). Sedangkan penyebarannya di luar wilayah Indonesia meliputi Burma, Thailand, Indocina, Malaysia, Filipina (Lekagul dan McNeely 1977), serta Vietnam, Laos, dan Singapura (Corbet dan Hill 1992).

\section{Anatomi Tubuh Trenggiling ( $M$. javanica)}

Trenggiling (M. javanica) disebut juga $M$. leptura (Blyth 1842) atau M. leucura (Blyth 1847) mendiami daerah hutan hujan tropis di Asia Tenggara dan mempunyai morfologi tubuh yang unik (Corbet dan Hill 1992). Pada permukaan tubuh bagian dorsal terdapat sisiksisik yang keras dan diantara sisik tersebut terdapat rambut-rambut yang kasar, Sedangkan pada bagian ventralnya tidak terdapat sisik tetapi hanya terdapat rambut-rambut. Panjang tubuh hewan ini dari kepala hingga ekor dapat mencapai $7988 \mathrm{~cm}$. Ukuran tubuh trenggiling jantan lebih panjang dibandingkan dengan betina (Breen 2003).

Tubuh trenggiling yang panjang ditunjang oleh empat kaki yang pendek dan masingmasingjarinya mempunyai cakar yang panjang dan melengkung. Cakar pada kaki depan biasanya lebih panjang hingga 11/2 kali daripada cakar kaki belakang. Cakar pada 
kaki depan berperan sangat penting ketika trenggiling menggali lubang semut atau rayap (Lekagul dan McNeely 1977). Kepalanya kecil dan berbentuk tirus dengan mata yang kecil dan dilindungi oleh kelopak mata yang tebal. Kelopak matanya tersebut merupakan pelindung mata dari gigitan semut. Memiliki daun telinga yang berukuran kecil dan berbentuk seperti bulan sabit. Dari ruang mulutnya dapat dijulurkan lidah yang berbentuk seperti cacing dan sangat lengket (Amir 1978). Lidah trenggiling merupakan lidah yang terpanjang, ketika dijulurkan dapat mencapai $25 \mathrm{~cm}$ (Breen 2003). Hal tersebut sangat membantu trenggiling ketika mencari pakan.

\section{A. Tingkah Laku Trenggiling ( $M$. javanica) di alam}

Trenggiling termasuk mamalia pemakan semut sehingga sering disebut anteater (Feldhamer et al. 1999). Pakan utama dari trenggiling ( $M$. javanica) adalah semut (Ordo Hymenoptera) dan rayap (Ordo Isoptera). Diantara keduanya, semut merah tanah (Myrmicaria sp) merupakan pakan yang lebih disukai (Heryatin 1983). Pakan tersebut tidak dihancurkan di dalam mulut karena trenggiling tidak mempunyai gigi, sehingga pakan digiling di dalam lambungnya dengan bantuan batu kerikil yang tertelan (Nisa' 2005). Selain itu trenggiling dapat melepaskan kotoran yang ikut melekat pada lidahnya ketika menangkap semut. Proses penyaringan ini terjadi di kerongkongan (Lekagul dan McNeely 1977). Proses mendapatkan pakan pada trenggiling tidak jauh berbeda dengan proses minum. Trenggiling mengeluarkan lidahnya dan memasukkannya kembali dengan cepat ketika minum (Nowak 1999).

Dalam aktivitas mendapatkan pakan, trenggiling menggunakan indera penciumannya untuk mendapatkan semut atau rayap. Indera penciuman merupakan indera penting untuk kelangsungan hidup trenggiling terkait dengan pencarian pakannya. Sebelum menggali sarang semut atau rayap, trenggiling membaui daerah yang diduga terdapat banyak semut atau rayap. Setelah menemukan tempat yang diinginkan, trenggiling menggali dengan cakar kaki depannya hingga semut atau rayap keluar dari sarang. Selanjutnya trenggiling mulai menangkap semut atau rayap tersebut dengan lidahnya yang panjang dan lengket (Attenborough 2004).

Aktivitas seekor trenggiling dapat berlangsung sepanjang hari tetapi lebih tinggi ketika malam hari (nokturnal). Pada siang hari trenggiling lebih banyak menghabiskan waktunya untuk tidur di dalam lubang-lubang atau di bawah dedaunan atau dicelah-celah pohon (Amir 1978). Trenggiling mempunyai kaki yang dilengkapi dengan bantalan di telapaknya dan kukukuku yang panjang dan melengkung. Biasanya kuku kaki depannya lebih panjang serta kuat dibandingkan kuku kaki belakangnya (Corbet dan Hill 1992; Nowak 1999). Trenggiling sangat pandai memanjat dibandingkan dengan berjalan. Mereka merupakan penggali yang kuat dan akan membuat lubang di bukit rayap serta sarang semut untuk mendapatkan pakan (Medway 1969). Dalam usaha mendapatkan pakan, penciuman merupakan organ sensori yang berperan utama membantu menemukan sarang rayap atau semut. Kegiatan ini dibantu dengan indera pendengaran tetapi tidak dengan penglihatannya yang buruk (Lekagul dan McNeely 1977).

Trenggiling ( $M$. javanica) muda mulai mencari lawan jenis sekitar umur satu tahun. Pada saat itu organ reproduksinya telah siap secara anatomis maupun fungsinya. Trenggiling jantan harus bersaing dengan trenggiling jantan lainnya untuk mendapatkan betina (Medway 1969). Anak yang dilahirkan ratarata Hanya satu hingga dua ekor untuk setiap kelahiran. Lama seekor trenggiling menyusui anaknya ratarata 130 hari (Breen 2003).

Predator utama dari trenggiling antara lain manusia, macan (Panthera pardus), dan phyton (Breen 2003). Trenggiling menyelamatkan dirinya dari predator-predator tersebut dengan berbagai cara. Dimulai dengan menegakkan sisik, melingkarkan badan hingga menyemprotkan cairan berbau busuk dari kelenjar anal untuk mengusir predatorpredator tersebut (Feldhamer et al. 1999). 


\section{B. Tingkah Laku Trenggiling (M. javanica) di penakaran}

Pengamatan dan pencatatan perilaku dilakukan dengan mengklasifikasikan ke dalam jenis perilaku bergerak, tidur dan makan mulai dari awal kegiatan berupa aktivitas gerak hingga berakhirnya aktivitas yaitu tidur. Pola penggunaan waktu harian ternyata bervariasi secara individu menurut umur, siklus biologi, status sosial, musim, dan karakteristik ekologi habitat (Santosa, 1993).

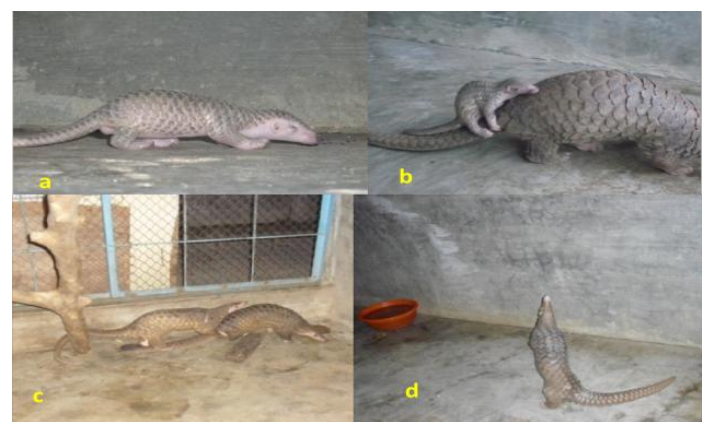

Gambar 3. a dan b, anak trenggiling yang baru lahir; c, trenggiling berpasangan; dan d, trenggiling sedang berdiri. (Sumber: Sawitri 2012)

\section{Perilaku Bergerak}

Perilaku bergerak berupa aktivitas berjalan, mendatangi pakan, memanjat dan berdiri.Aktivitas berjalan yaituaktivitas berpindah tempat di atas lantai menggunakan keempat tungkai dan dilakukan segera setelah bangun dari tidur, kemudian menuju tempat pakan atau minum atau sekedar berjalan memeriksa lingkungan sekitar. Aktivitas berjalan menuju tempat pakan atau minum dipengaruhi oleh suhu yang cukup tinggi dalam kandang dan sebagai bentuk adaptasi tingkah laku terhadap perubahan suhu pada pagi, siang, dan sore hari serta suatu mekanisme untuk mengimbangkan suhu tubuh dengan lingkungan (Novriyanti, 2011).

Aktivitas memanjat dilakukan dengan gerakan vertikal dari lantai atau kandang bagian bawah lalu naik ke atas batang pohon atau kawat ram pada kandang bagian atas, menggunakan variasi antara keempat tungkainya. Kedua kaki depan digunakan untuk menarik tubuhnya ke atas dan kedua kaki belakang digunakan untuk mendorong tubuhnya dari bawah. Aktivitas ini banyak dilakukan, baik di kandang individu maupun berpasangan. Trenggiling yang berpasangan, terlihat jantannya lebih aktif bergerak memanjat kawat naikturun. Hal ini dilakukan untuk melatih otot kaki, karena kedua kakinya sangat bermanfaat pada saat menaiki betina.

Aktivitas berdiri lebih banyak dilakukan oleh trenggiling jantan dalam kandang individu yakni apabila merasa terganggu oleh gangguan, baik suara maupun gerakan dengan cara membaui. Aktivitas berdiri dilakukan dengan dua kaki belakang dan menegakkan tubuh, yang bertujuan mengamati lingkungan sekitar dengan cara mendengus atau membaui. Hal ini sesuai dengan sifat trenggiling sebagai satwa soliter (Medway, 1969), sehingga kehadiran sesuatu yang baru akan sangat mengganggu. Mendatangi pakan adalah aktivitas mendekati pakan atau minum yang diberikan, dilakukan bersamaan dengan membersihkan tubuh dengan cara mandi di bak air yang umumnya dilakukan setelah defekasi.

\section{Perilaku Tidur}

Pengamatan perilaku tidur pada trenggiling di dalam kandang berlangsung lama dengan frekuensi yang kecil dan biasanya dilakukan sepanjang siang sampai sore hari. Trenggiling lebih banyak tidur pada siang hari, sehingga di penangkaran satwa ini tetap sebagai satwa yang nokturnal sebagaimana di alam (Medway, 1969). Aktivitas ini dilakukan sepanjang siang hari sampai matahari terbenam. Apabila cuaca panas, satwa ini akan bangun untuk sekedar membasahi tubuhnya dengan mencelupkan muka dan badannya ke dalam bak air, kemudian kembali tidur. Saat melingkar, badan digulung seperti bola kemudian kepala dan keempat kakinya menyentuh perut. Posisi tidur melingkar yang umum 
dilakukan trenggiling adalah untuk menghindari adanya gangguan dengan cara menyembunyikan kepala dan bagian tubuh lainnya yang sangat lunak dan tidak bersisik (Abdurahim, 2006). Saat terlentang, trenggiling ada di atas lantai kemudian kakinya mencengkeram kawat, ekor ditekuk ke dalam dan lidahnya dijulurkan terutama pada saat panas terik, bahkan trenggiling sering mengeluarkan air ludah (saliva) yang lengket dari mulutnya.

Selain itu, pada saat cuaca panas dan suhu tinggi trenggiling biasanya tidur di dalam bak air untuk mendinginkan badan sebagai salah satu bentuk adaptasi tubuh terhadap lingkungan kandang. Hal ini dilakukan agar trenggiling tidak mengalami dehidrasi. Oleh karena itu, di dalam kandang harus disediakan bak atau kolam yang berisi air untuk mendinginkan suhu tubuh. Posisi tidur melingkar lebih banyak dilakukan oleh trenggiling betina ataupun yang berpasangan, di mana mereka saling melingkarkan badan dan menyusupkan kepala satu sama lain terutama pada betina yang sedang bunting.

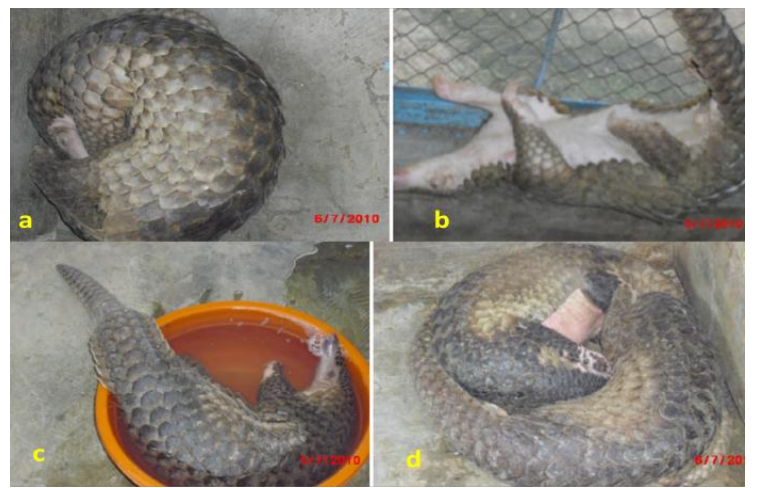

Gambar 4. a, salah satu posisi tidur trenggiling; b, posisi tidur jantan remaja; c, posisi berendam dalam air; dan d, posisi tidur trenggiling berpasangan (Sumber: Sawitri 2012)

\section{Perilaku Makan}

Perilaku makan pada satwa meliputi bahan makanan yang dikonsumsi, baik cair maupun padat dan polanya berhubungan dengan anatomi dan fisiologi. Sebelum mengkonsumsi pakan, trenggiling mendengus dan menciumi pakan lalu menjulurkan lidahnya secara cepat dan kadang-kadang kedua kaki depan dimasukkan ke dalam tempat makan. Menurut Suratmo (1979), perilaku makan berhubungan dengan ketersediaan pakan, habitat atau lingkungan, musim, gangguan, kondisi biologis, dan cara makan.

Demikian pula menurut Warsono (2002) bahwa perilaku makan dipengaruhi oleh faktor genetik, suhu lingkungan, jenis pakan yang tersedia, dan habitat. Pengamatan perilaku ini berhubungan langsung dengan aktivitas makan, yaitu bagaimana cara trenggiling mengambil pakan, aktivitas minum yaitu memasukkan air atau cairan ke dalam tubuh melewati mulut, aktivitas defekasi yaitu mengeluarkan kotoran dalam bentuk padat, dan aktivitas urinasi yaitu mengeluarkan kotoran berbentuk cair. Menurut Tomaszewska et al. (1991), tingkah laku makan, minum, dan kegiatan lain yang berhubungan dengan hal tersebut (defekasi dan urinasi), digolongkan ke dalam tingkah laku ingestif.

Trenggiling di diberi pakan kroto yang dicampur dedak dan jagung halus. Umumnya kroto yang dikonsumsi lebih dahulu dan apabila kroto sudah mulai berkurang, trenggiling tidak mau mengkonsumsinya lagi. Sering terlihat pakan ditumpahkan ke lantai kemudian lidahnya dijulurkan untuk mencari dan mengambil sisa kroto yang terdapat dalam campuran pakan tersebut. Church (1976) dalam Pratiwi (2008) mengatakan, hewan memiliki sifat seleksi yang cukup tinggi terhadap pakan yang tersedia, sehingga akan lebih banyak memakan jenis pakan yang paling disukainya. 


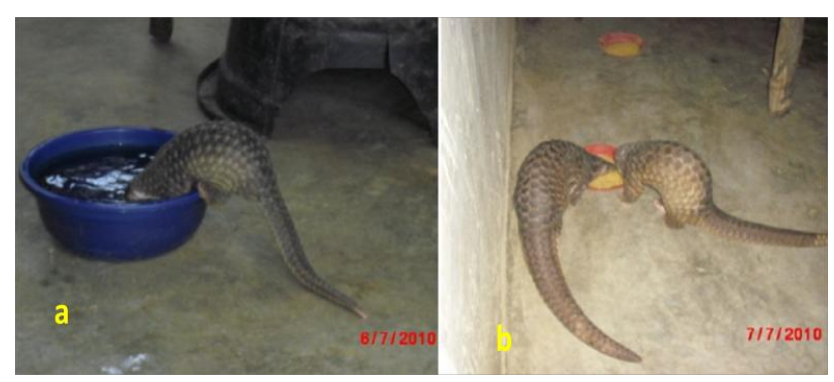

Gambar 5. a, trenggiling sedang minum; b, Pasangan trenggiling sedang makan (Sumber: Sawitri 2012)

Aktivitas minum dipengaruhi oleh kondisi cuaca panas dan suhu tinggi sehingga trenggiling lebih sering minum. Kondisi ini berlainan dengan situasi di alam, di mana lingkungannya lebih dingin dan sesuai dengan suhu tubuh trenggiling seperti pada lubang dalam tanah atau pohon (Nowak, 1999). Aktivitas minum dilakukan dengan cara kepala dimasukkan ke dalam bak air kemudian lidah dijulurkan dengan cara menyerap, kadangkadang kedua kaki depan dimasukkan dalam bak air. Defekasi dan urinasi dilakukan setiap hari secara tidak bersamaan dengan frekuensi secara keseluruhan.

\section{Perilaku Seksual}

Sebagaimana dikemukakan di atas indikator kunci dari keberhasilan penangkaran satwa adalah apabila penangkaran tersebut berhasil mengembangbiakan satwa yang ditangkarkan. Ada beberapa hal yang terkait dengan manajemen pengembangbiakan trenggiling, yakni pengenalan tentang karakteristik bioreproduksi (usia dewasa kelamin, musim kawin, lama kebuntingan, jumlah anak per kelahiran, determinasi sex) dan teknik pengembangbiakan (Masy'ud \& Bismark, 2011).

Trenggiling memiliki organ reproduksi yang terdiri atas sepasang testes, epididymis dan ductus deferens yang selanjutnya bermuara ke urethra yang terdapat di dalam penis. Sepasang testes ascrotalis (tidak terbungkus oleh scrotum) terletak di subcutanea daerah inguinales (Akmal et al., 2014a Akmal et al., 2014b). Kerena tidak adanya scrotum pada trenggiling maka diduga tidak terlalu berpengaruh pada proses spermatogenesis. Pada hewan yang tidak memiliki scrotum, perkawinan akan dilakukan dengan meng- hindari radiasi langsung dari sinar matahari dengan mencari tempat di bawah tanah atau berada di gua- gua (Brice et al., 2002) dan dilakukan pada malam hari. Hewan dengan testes ascrotalis masih dapat menjaga keberlangsungan keturunannya, tetapi membatasi kapasitas mereka untuk bereproduksi sepanjang tahun (Jones et al., 2004). Kelenjar asesoris trenggiling jantan terdiri atas glandula vesicularis dan prostata serta glandula bulbourethralis (Akmal et al., 2015; Akmal et al., 2019).

Histologi testis trenggiling disusun oleh tubuli seminiferi yang dipisahkan oleh jaringan interstisial. Membran basal tubuli seminiferi, terdiri dari sel-sel epitel germinal (spermatogonia, spermatosit dan spermatid) dan sel Sertoli, sedangkan pada jaringan interstisial terdapat sel-sel Leydig dan pembuluh darah. Proses spermatogenesis pada tubuli seminiferi trenggiling menunjukkan perkembangan sepermatogonia menjadi spermatid sampai spermatozoa menjadi delapan tahapan (Akmal dan Mahfud 2019).

Pada umumnya trenggiling merupakan hewan nokturnal dan terestrial, kecuali $M$. tetradactyla yaitu diurnal dan arboreal. Pada siang hari trenggiling lebih banyak menghabiskan waktunya untuk tidur di dalam lubang-lubang atau dibawah dedaunan atau di celah-celah pohon (Rahm 1990).

Secara alami, trenggiling termasuk satwa kawin bermusim yakni kawin pada bulan April-Juni, namun di penangkaran dalam beberapa laporan diketahui bahwa trenggiling dapat kawin sepanjang tahun. Dengan kalimat lain terjadi perubahan pola aktivitas kawin dari pekawin bermusim (seasonal breeder) menjadi pekawin tidak bermusim (unseasonal breeder). Secara alami kondisi ini dapat dimungkinkan terutama karena ketersedian pakan di penangkaran yang selalu ada sementara di alam sangat tergantung pada musim. Selain 
itu, kemajuan bioteknologi reproduksi memungkinkan dilakukan pengaturan perkawinan satwa di penangkaran (Masy'ud \& Bismark, 2011).

\section{Daftar Pustaka}

Abdurahim. (2006). Salah satu jenis satwa dilindungi yang ada di Pegunungan Meratus. Banjarbaru: Yayasan Cakrawala Hijau Indonesia

Adiseno. (2008, Oktober 20). Belasan trenggiling dari Mentawai disita. Sinar Harapan.

Akmal, Y., Nisa, C., \& Novelina, S. (2014a). Anatomi Organ Reproduksi Jantan Trenggiling (Manis javanica). Acta Veterinaria Indonesiana, 2(2), 74-81.

Akmal, Y., Nisa, C., \& Novelina, S. (2014b). Anatomy of the Male Reproductive Organs of Javan Pangolin (Manis javanica). In Proceeding the 3 Joint International Meeting Bogor Indonesia P-03: 1 (Vol. 2). Hal: 69-70.

Akmal, Y., Muliari, Nisa, C., \& Novelina, S. (2015). Anatomy Accessory Glands Of Male Reproductive Of Javan Pangolin (Manis javanica). In Proceeding the 1th Almuslim International Conference on Science, Technology and Society (AICSTS), 1(1) Hal: 192-197.

Akmal, Y., Nisa, C., \& Novelina, S. (2019). Morfologi Kelenjar Aksesori Kelamin Jantan pada Trenggiling (Manis javanica) (Morphology Of The Male Sex Accessory Glands Of The Pangolin (Manis javanica)). Jurnal Veteriner, 20(36), 38-47. https://doi.org/10.19087/jveteriner.2019.20.1.38

Akmal, Y., \& Mahfud (2019). Spermatogenesis dan Histologi Testis Trenggiling Jantan (Manis javanica). In Prosiding Semdi-Unaya (Seminar Nasional Multi Disiplin IImu UNAYA) (Vol. 3, No.1).

Alikodra HS. 1990. Pengelolaan Satwa Liar. Jilid I. Bogor. Yayasan Penerbit Fakultas Kehutanan Institut Pertanian Bogor

Amir H. 1978. Mamalia di Indonesia, Pedoman Inventarisasi Satwa. Direktorat Perlindungan dan Pengawetan Alam, Direktorat Jendral Kehutanan. Bogor.

Attenborough, D. 2004. The Life of Mammals. Vol.2. Video CD. England: BBC Worldwide Limited.

Breen, K. 2012. "Manis javanica", Animal Diversity Web, Museum of Zoology. University of Michigan. http://animaldiversity.ummz.umich.edu. [10 Mai 2013].

Corbet G dan J Hill. 1992. Mammals of Indoalayan Region. Oxford: Natural History Museum, London and Oxford University Press.

Pratiwi, N. A. (2008). Aktivitas pola makan dan pemilihan pakan pada lutung kelabu betina (Trachypithecus cristatus, Raffles 1812) di Pusat Penyelamatan Satwa Gadog Ciawi -Bogor (Skripsi). Program Studi Ilmu Nutrisi dan Makanan Ternak Fakultas Peternakan, Institut Pertanian Bogor. Bogor.

Feldhamer, GA, CL Drickamer, SH Vessey, JF Merritt. 1999. Adaptation, Diversity, and Ecology Mamalogy. Boston : The McGrawHill Companies. hIm. 85, 252.

Gaubert, P dan A Antunes. 2005. Assesing the Taxonomic Status of the Palawan Pangolin Manis culionensis (Pholidota) Using Discrete Morphological Characters. Jurnal of Mammalogy, 86 (6): 1068-1074.

Hamzah, E. (2012, Juni 15). Menteri Kehutanan musnahkan 12,7 ton trenggiling ilegal. Retrieved from http: //www.tempo.co/read/news/2012/0 6/15/090410826/Menteri- Kehutanan-Musnahkan-127-Ton- Tenggilingllegal.

Heryatin, T. 1983. Beberapa Aspek Trenggiling Di Suaka Alam Gunung Honje Timur dan Perkebunan Teh Cigombong, Cisadea Cianjur Selatan [skripsi]. Program Studi Biologi (S1) Universitas Negeri Padjajaran Bandung. Bandung.

Lekagul, B dan JA McNeely. 1977. Mammals of Thailand. Association for the Concervation of Wildlife, Sahakarnbhat co., Bangkok.

Medway, L. 1969. The Wild Mammals of Malaya. London : Oxford University Press.

Nisa' C. 2005. Morphological Studies of The Stomach of Malayan Pangolin (Manis javanica) [disertasi]. Graduate School Bogor Agricultural University, Bogor.

Novriyanti. 2011. Kajian Manajemen Penangkaran, Tingkat Konsumsi, Palatabilitas Pakan, Dan Aktivitas Harian Trenggiling (Manis javanica Desmarest, 1822) Di Penangkaran Ud Multi Jaya Abadi Sumatera Utara. [Skripsi]. Fakultas Kehutanan, Institut Pertanian Bogor

Nowak, R. 1999. Walker's Mammals of The World. Ed ke6. Baltimore: The Jhons Hopkins University Press.

Robinson, PT. 2005 . Zoo and Wild Animal Medicine. Ed ke5. Saunders.

Santosa, Y. (1993). Strategi kuantitatif untuk pendugaan beberapa parameter demografi dan kuota pemanenan populasi satwaliar berdasarkan pendekatan ekologi perilaku. Studi kasus terhadap populasi rusa jawa (Cervus timorensis) di Pulau Peucang (Laporan Penelitian). Fakultas Kehutanan, IPB. Bogor.

Sawitri RM. Bismark, dan Takandjandji M. 2012. Perilaku Trenggiling (Manis javanica Desmarest, 1822) di Penangkaran Purwodadi, Deli Serdang, Sumatera Utara Pusat Litbang Konservasi dan Rehabilitasi.

Soehartono T, Mardiastuti A. 2003. Pelaksanaan Konvensi CITES di Indonesia. Jakarta: JICA. HIm 24. 
Suratmo, F. G. (1979). Prinsip dasar tingkah laku satwaliar. Bogor: Institut Pertanian Bogor Press.

Tethool AN, 2011. Karakteristik Reproduksi Bandikut (Echymipera kalubu) Jantan [tesis]. Bogor : Sekolah Pascasarjana, Institut Pertanian Bogor.

Tomaszewska, M.W, Sutama, I. K., Chaniago, T. D. (1991). Reproduksi, tingkah laku, dan produksi ternak di Indonesia. Jakarta: Gramedia Pustaka Utama.

Warsono, I. U. (2002). Pola tingkah laku makan dan kawin burung kasuari (Casuarrius sp.) dalam penangkaran di Taman Burung dan Taman Anggrek Biak. Retrieved from http: //rudict.tripod.com/Sem 1-023.

Masy'ud, B., \& Bismark, M. (2011). Perilaku Trenggiling (Manis Javanica, Desmarest, 1822) dan Kemungkinan Penangkarannya. Media Konservasi, 16(3). 